\title{
Article
}

\section{Ionic covalent organic frameworks for highly effective catalysis}

\author{
Hui Hu a, Qianqian Yan a, Ming Wang a, Li Yu b, Wei Pan c, Baoshan Wang d, Yanan Gao a,* \\ a Key Laboratory of Ministry of Education for Advanced Materials in Tropical Island Resources, Hainan University, Haikou 570228, Hainan, China \\ b Key Laboratory of Colloid and Interface Chemistry, Ministry of Education, Shandong University, Jinan 250100, Shandong, China \\ c College of Chemistry, Chemical Engineering and Materials Science Engineering, Shandong Normal University, Jinan 250014, Shandong, China \\ d College of Chemistry and Molecular Sciences, Wuhan University, Wuhan 430072, Hubei, China
}

\section{A R T I C L E I N F}

\section{Article history:}

Received 15 Feburary 2018

Accepted 23 March 2018

Published 5 September 2018

\section{Keywords:}

Covalent organic framework

Ionic architecture

Catalyst

Epoxidation

Porous material

\begin{abstract}
A B S T R A C T
As an emerging class of crystalline porous materials, covalent organic frameworks (COFs) have been widely used as catalysts or catalyst supports. Flexible regulation of the pores and easy introduction of functional active sites onto the skeleton of COFs make them promising platforms for many catalysis applications. However, only a single function is generally observed in these COFs. Herein, we synthesized a negatively charged ionic COF (I-COF) and successfully incorporated functionalized counter ions, that is, metallic $\mathrm{Mn}^{2+}$ and a coordination complex of manganese(II) bipyridine complexes ([Mn(bpy) $\left.]_{2}\right]^{2+}$ ), via a simple ion exchange process. The resulting I-COFs can act as effective heterogeneous catalysts for epoxidation reactions. We envisage that with this type of ionic architecture, a variety of other functional cations could be exchanged into the frameworks, thus making the COF a versatile platform for different applications.
\end{abstract}

(C) 2018, Dalian Institute of Chemical Physics, Chinese Academy of Sciences. Published by Elsevier B.V. All rights reserved.

\section{Introduction}

Covalent organic frameworks (COFs) are a series of crystalline porous materials composed of light elements (e.g., C, $\mathrm{H}, \mathrm{N}$, $B, 0)[1-4]$. COFs have been extensively studied in recent years because of their potential applications in various areas, such as gas storage/separation [5-9], sensing [10,11], and energy conversion [12-19]. Moreover, flexible regulation of the pores and easy introduction of functional active sites onto the skeleton of COFs make them promising platforms for many catalysis applications. Thus, many efforts have been focused on either post-synthetic modification or a bottom-up strategy that was shown to be successful in the introduction of catalytic active sites [20-27]. In contrast to post-synthetic modification, the bottom-up strategy generally requires a tedious solvothermal condition, particularly if a bulky catalytic site is attached to building units, it will be difficult to obtain crystalline COFs. Post-synthetic modification is relatively easy and simple, but this strategy generally endows the resulting COFs with only a certain function. To optimize a COF for use in a wide variety of different applications, it is important to be able to tailor its functionality in a straightforward fashion.

Nanosized pores in ionic architectures exhibit unique properties in terms of adsorption and separation of gas molecules $[28,29]$. This charged nature also enables ionic materials to permanently incorporate, through ion exchange, other extra-framework counter ions, thus making it possible to obtain special properties, such as those useful in chemical sensing, photonics, and catalysis, to realize many unconventional applications [30]. Ionic COFs (I-COFs) have recently been reported, and these ionic frameworks exhibit exceptional proton/ion conduction, electrolyte performance, and removal of pollutants

* Corresponding author. Tel/Fax: +86-898-66279161; E-mail: ygao@hainu.edu.cn

This work was supported by the National Natural Science Foundation of China (21473196, 21676264), the 100-Talents Program of CAS, and the State Key Laboratory of Fine Chemicals, Dalian University of Technology (KF1415).

DOI: 10.1016/S1872-2067(18)63065-7 | http://www.sciencedirect.com/science/journal/18722067 | Chin. J. Catal., Vol. 39 , No. 9 , September 2018 
[31-34]. However, little research has been done on the utilization of I-COFs for catalysis by far. It is known that many positively charged species, including metal ions and coordinated metal complexes, exhibited excellent catalytic performance, and their high catalytic activity remained when they were loaded within the ionic framework as counter ions. Therefore, we expect that I-COFs can be used as versatile catalysts that maintain the high catalytic activity of either metal ions or coordinated metal complexes. Moreover, the high porosity, designable topology, and easy modification of I-COFs make them ideal materials for catalysis applications.

Herein, we report the synthesis of a negatively charged I-COF through a post-synthetic modification strategy. A chemically stable imine-based COF, DhaTab, was first constructed by the condensation reaction of 2,5-dihydroxyterephthalaldehyde (Dha) and 1,3,5-tris(4-aminophenyl)benzene (Tab) [35]. The ring-opening reaction of 1,3-propane sultone with phenolic hydroxyl on the skeleton of DhaTab affords a sulfoacid-based $\mathrm{COF}$ material. In the presence of a dilute $\mathrm{NaOH}$ solution, two different counter ions, metallic $\mathrm{Mn}^{2+}$ and a coordination complex of manganese(II) bipyridine complexes ([Mn(bpy) $\left.]^{2+}\right]^{2}$, were successfully incorporated via a simple ion exchange process (Scheme 1). The resulting I-COFs, as heterogeneous catalysts, exhibited excellent catalytic activities in epoxidation reactions. The proposed I-COF strategy provides a promising platform for the development of versatile materials for catalysis.

\section{Experimental}

\subsection{Materials}

All starting materials and solvents, unless otherwise specified, were obtained from commercial sources and used without further purification. Dha was synthesized according to a previously published procedure [36]. All reactions were performed under ambient laboratory conditions, and no precautions were taken to exclude oxygen or atmospheric moisture, unless otherwise specified.

\subsection{Synthesis of DhaTab COF}

A pyrex tube was charged with Tab $(0.16 \mathrm{mmol}, 56 \mathrm{mg})$ and Dha $(0.24 \mathrm{mmol}, 32 \mathrm{mg}), 1.0 \mathrm{~mL}$ of ortho-dichlorobenzene (o-DCB), $1.0 \mathrm{~mL}$ of $n$-butanol, and $0.2 \mathrm{~mL}$ of $6 \mathrm{~mol} \mathrm{~L}^{-1}$ acetic acid. This mixture was sonicated for $5 \mathrm{~min}$ and then flash-frozen at $-196{ }^{\circ} \mathrm{C}$ (liquid $\mathrm{N}_{2}$ bath) and degassed by three freeze-pump-thaw cycles. The tube was sealed off and then heated at $120{ }^{\circ} \mathrm{C}$ for $3 \mathrm{~d}$. A yellowish precipitate appeared and was collected by filtration. The solid was then thoroughly washed with dimethylacetamide (DMAc), water, and then ethanol. The collected powder was solvent-exchanged with ethanol three times and then dried at $100{ }^{\circ} \mathrm{C}$ under vacuum overnight to give a yellowish powder in ca. $80 \%$ (38 mg) isolated yield. Elemental analysis (\%) calcd. for $\mathrm{C}_{60} \mathrm{H}_{48} \mathrm{~N}_{6} \mathrm{O}_{6}$ : $\mathrm{C}(75.92), \mathrm{H}$ (5.06), N (8.86); found C (73.36), H (4.51), N (7.69).

\subsection{Synthesis of $\left[\mathrm{SO}_{3} \mathrm{H}\right]-$ DhaTab $\mathrm{COF}$}

To $10.0 \mathrm{~mL}$ of a toluene suspension of DhaTab (10 mg) was added $5.0 \mathrm{~mL}$ of 1,3-propane sultone. The reaction was refluxed for $6 \mathrm{~h}$, and the solid was filtered and then thoroughly washed with DMAc, then water, and then ethanol. The solid

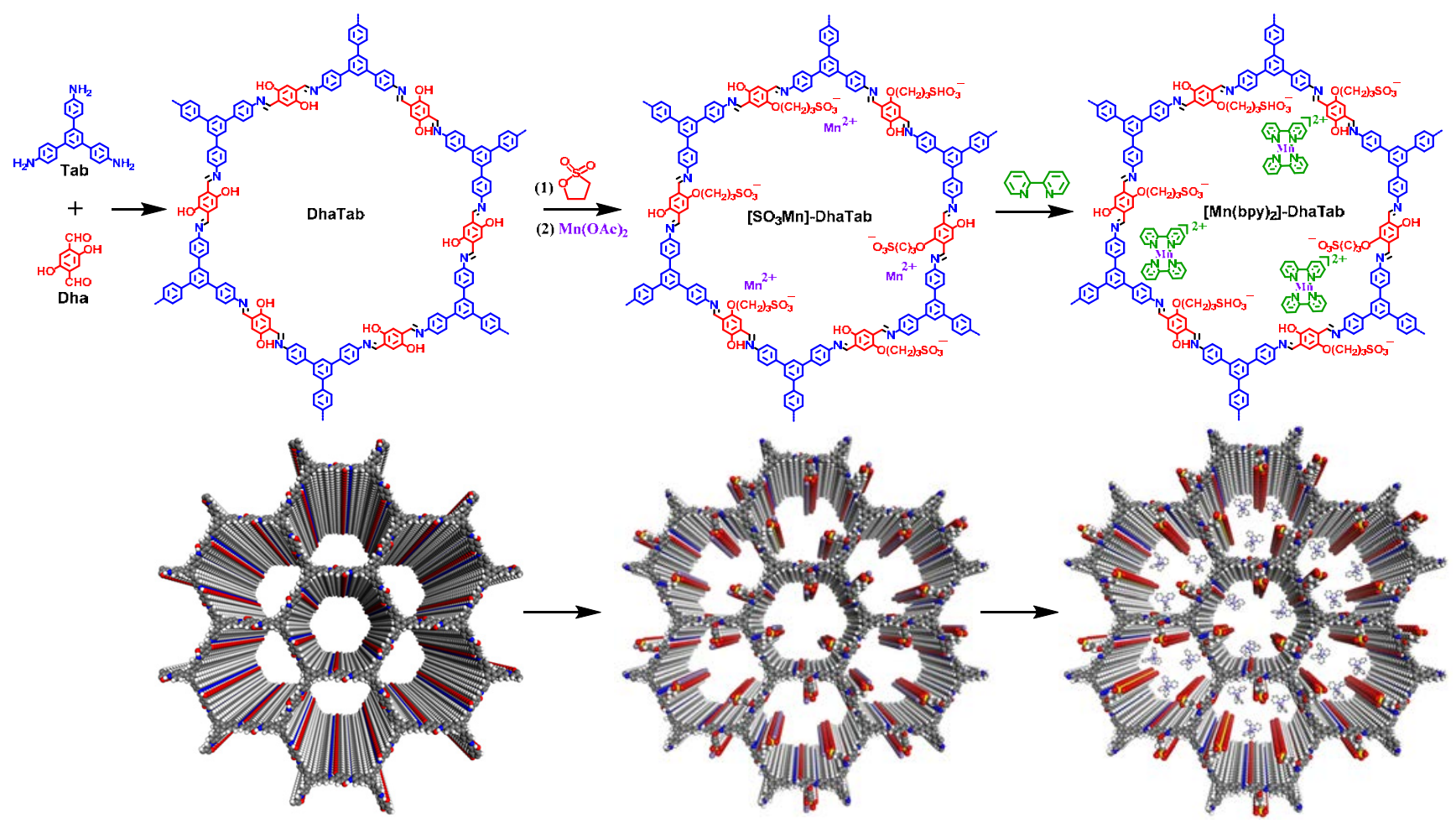

Scheme 1. Synthesis of DhaTab, [ $\left.\mathrm{SO}_{3} \mathrm{Mn}\right]-\mathrm{DhaTab}$, and [Mn(bpy) $\left.)_{2}\right]-\mathrm{DhaTab}$ COFs. 
was dried at $100{ }^{\circ} \mathrm{C}$ under vacuum overnight to give a deep red powder in $81 \%$ yield.

\subsection{Synthesis of $\left[\mathrm{SO}_{3} \mathrm{Mn}\right]-\mathrm{DhaTab} \mathrm{COF}$}

To $10.0 \mathrm{~mL}$ of a methanol suspension of $\left[\mathrm{SO}_{3} \mathrm{H}\right]$-DhaTab COF (10 mg) was added $10.0 \mathrm{~mL}$ of aqueous $\mathrm{NaOH} 1 \mathrm{~mol} \mathrm{~L}^{-1}$. The suspension was stirred for $2 \mathrm{~h}$, and the solid was filtered and washed with methanol three times. Next, the resulting [ $\mathrm{SO}_{3} \mathrm{Na}$ ]-DhaTab COF was added to $10.0 \mathrm{~mL}$ of a methanol solution containing $2 \mathrm{mg}$ of $\mathrm{Mn}(\mathrm{OAc})_{2}$. The mixture was stirred at $80{ }^{\circ} \mathrm{C}$ for $12 \mathrm{~h}$, and the solid was filtered and thoroughly washed with DMAc, then water, and then ethanol. The solid was dried at $100{ }^{\circ} \mathrm{C}$ under vacuum overnight to give a deep red powder in $92 \%$ yield.

\subsection{Synthesis of $\left[\mathrm{SO}_{3} \mathrm{Mn}(\mathrm{bpy})_{2}\right]$-DhaTab COF}

To $10.0 \mathrm{~mL}$ of a toluene suspension of [ $\left.\mathrm{SO}_{3} \mathrm{Mn}\right]$-DhaTab $(10$ $\mathrm{mg}$ ) was added $2 \mathrm{mg}$ of bipyridine. The reaction was refluxed at $120^{\circ} \mathrm{C}$ for $12 \mathrm{~h}$. The solid was thoroughly washed with toluene, then DMAc, then water, and then ethanol. The solid was dried at $100{ }^{\circ} \mathrm{C}$ under vacuum overnight to give a deep red powder in $87 \%$ yield.

\subsection{Epoxidation of olefins}

To take an example, [ $\left.\mathrm{SO}_{3} \mathrm{Mn}\right]$-DhaTab was selected as a catalyst for the epoxidation reaction. For the $\left[\mathrm{SO}_{3} \mathrm{Mn}\right]-\mathrm{DhaTab}-$ catalyzed epoxidation of stilbene to trans-stilbene oxide, stilbene (1.0 mmol), indole-3-butyric acid (IBA, $3.0 \mathrm{mmol}$ ), and [ $\mathrm{SO}_{3} \mathrm{Mn}$ ]-DhaTab (15 mg, containing about $0.005 \mathrm{mmol}$ of $\mathrm{Mn}$ ) in $\mathrm{CH}_{3} \mathrm{CN}(1.0 \mathrm{~mL})$ was stirred at room temperature for $12 \mathrm{~h}$ in air. The product was detected by ${ }^{1} \mathrm{H}$ nuclear magnetic resonance (NMR) using $\mathrm{CH}_{2} \mathrm{Cl}_{2}$ as an inter-standard.

\subsection{Characterization}

Elemental analysis was performed using an organic elemental analyzer (vario MACRO cube, Elementar, Germany). Inductively coupled plasma optical emission spectroscopy (ICP-OES) was conducted using an ICP-OES 7300DV apparatus (PerkinElmer). The sample was first calcined at $1000{ }^{\circ} \mathrm{C}$ in air for $12 \mathrm{~h}$ to burn out organic moieties. The residue was dissolved in aqua regia and then diluted by water for ICP-OES testing. Fourier transform infrared (FTIR) measurements were carried out on a Bruker spectrophotometer (Model TENSOR27) with powder-pressed $\mathrm{KBr}$ pellets. Powder X-ray diffraction (PXRD) analysis was carried out on a Rigaku RINT D/Max 2500 powder diffraction system using $\mathrm{Cu} K_{\alpha}$ radiation $(\lambda=1.5432 \AA)$. Thermogravimetric analysis (TGA, STA449F3, NETZSCH, Germany) was performed from room temperature to above $750{ }^{\circ} \mathrm{C}$ at a heating rate of $10{ }^{\circ} \mathrm{C} \mathrm{min}^{-1}$ and a $\mathrm{N}_{2}$ flow rate of $20.0 \mathrm{~mL}$ $\mathrm{min}^{-1}$. A nitrogen physisorption experiment was conducted at $-196{ }^{\circ} \mathrm{C}$ on a QUADRASORB SI gas sorption system (Quantachrome Instruments), which was degassed at $120{ }^{\circ} \mathrm{C}$ under vacuum before testing. Brunauer-Emmett-Teller (BET) analysis was used to determine the specific surface areas $\left(\mathrm{m}^{2}\right.$ $\left.\mathrm{g}^{-1}\right)$ using desorption branches over 0.003-0.051 $\left(P / P_{0}\right)$. The micropore volumes $\left(V_{\mathrm{p}}, \mathrm{cm}^{3} \mathrm{~g}^{-1}\right)$ were determined using the Dubinin-Radushkevich model of nitrogen isotherms across the region of $0.01<P / P_{0}<0.23$. In all the isotherm plots, filled circles indicate adsorption data points, and open circles represent desorption data points. The pore size distribution of all the COFs was calculated from the adsorption isotherms by the nonlocal density functional theory (NLDFT) method using the Ar-zeolite/silica cylindrical pores at $-186{ }^{\circ} \mathrm{C}$ kernel (applicable pore diameters, $3.5-1000 \AA$ ) as implemented in the AUTOSORB iQwin data reduction software (version 3.01). X-ray photoelectron spectroscopy (XPS) was performed using an ESCALAB 250Xi spectrometer equipped with $\mathrm{Al} K_{\alpha}$ radiation $(1486.6 \mathrm{eV}$, $200 \mathrm{~W}$ ) on sample powder-pressed pellets. ${ }^{1} \mathrm{H}$ and ${ }^{13} \mathrm{C}$ NMR spectra were recorded by a Bruker Advance III $400 \mathrm{MHz}$ NMR spectrometer (Bruker BioSpin Corporation, Fällanden, Switzerland).

\section{Results and discussion}

\subsection{Characterization of COFs}

The formation of DhaTab was confirmed by FTIR spectroscopy, where a characteristic peak of imine appeared at 1612 $\mathrm{cm}^{-1}$ (Fig. 1). The crystallinity of DhaTab was determined from PXRD data (Fig. 2). Diffraction peaks appeared at $2 \theta=2.8^{\circ}, 4.9^{\circ}$, $5.6^{\circ}, 7.4^{\circ}, 9.8^{\circ}$, and $26.3^{\circ}$, which correspond to the (100), (110), (200), (120), (220), and (001) facets, respectively. The use of the lattice modeling and Pawley refinement processes produced an eclipsed AA stacking model that could reproduce the PXRD results in terms of the peak position and intensity. In contrast, an alternatively staggered $\mathrm{AB}$ model did not match the observed data (not shown here). The unit cell was created with a P3 space group of $a=b=36.2 \AA, c=3.4 \AA$, and $\alpha=\beta=90^{\circ}, \gamma=$ $120^{\circ}$. After the alkyl sulfonic acid group was linked, the modified $\mathrm{COF},\left[\mathrm{SO}_{3} \mathrm{H}\right]-\mathrm{DhaTab}$, exhibited an XRD pattern similar to that of DhaTab, indicating that it possesses a similar crystal structure. After ion exchange, the pristine crystal structure of DhaTab remained (Fig. 3). Successful introduction of the alkyl

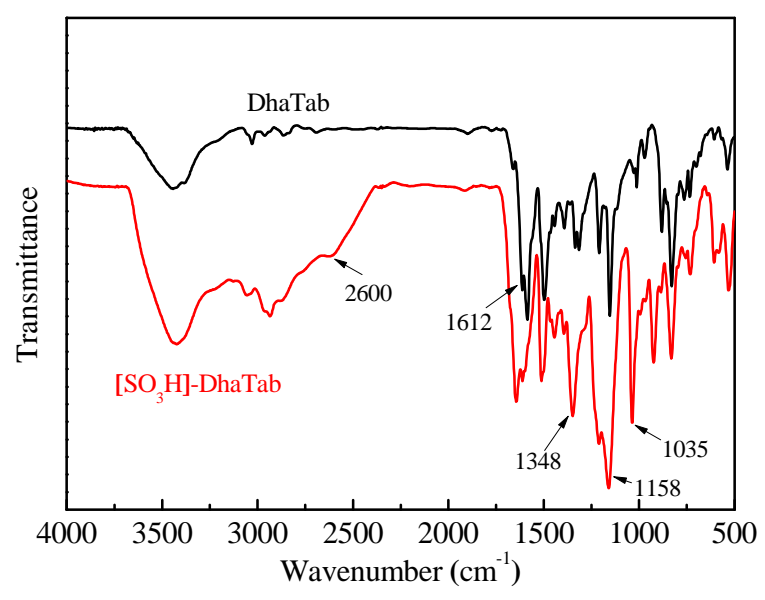

Fig. 1. FTIR spectra of DhaTab and $\left[\mathrm{SO}_{3} \mathrm{H}\right]-$ DhaTab COFs. 


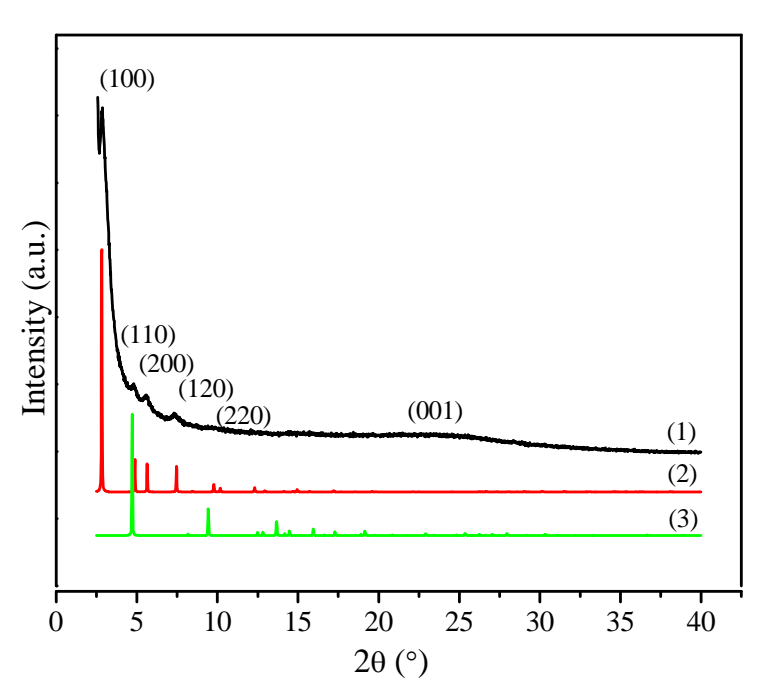

Fig. 2. Experimental PXRD pattern of DhaTab (1) compared with those of simulated eclipsed (2) and staggered (3) models.

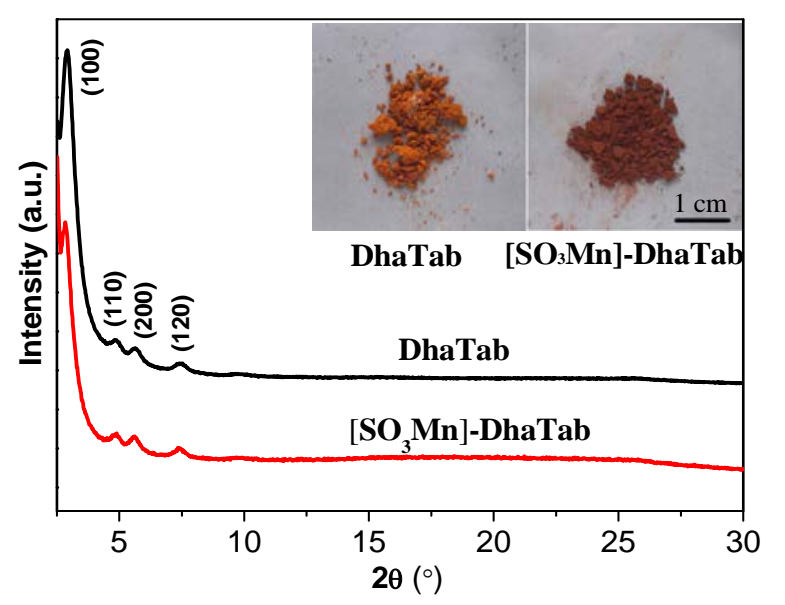

Fig. 3. PXRD patterns of DhaTab and $\left[\mathrm{SO}_{3} \mathrm{Mn}\right]-\mathrm{DhaTab}$. Inset: images of DhaTab and $\left[\mathrm{SO}_{3} \mathrm{Mn}\right]$-DhaTab.

sulfonic acid group on the skeleton was confirmed by FTIR spectroscopy, where the characteristic stretching peaks of

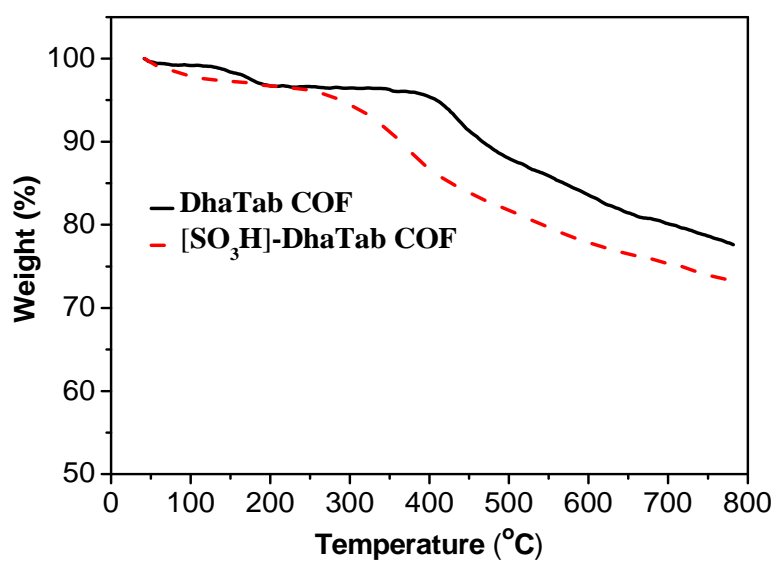

Fig. 4. TGA curves of DhaTab and $\left[\mathrm{SO}_{3} \mathrm{Mn}\right]-\mathrm{DhaTab}$ COFs.

- $\mathrm{SO}_{3} \mathrm{H}$ appeared at 2600, 1348, 1158, and $1035 \mathrm{~cm}^{-1}$ (Fig. 1). TGA revealed that both DhaTab and $\left[\mathrm{SO}_{3} \mathrm{H}\right]$-DhaTab exhibited high thermal stability with a decomposition temperature above $300{ }^{\circ} \mathrm{C}$ (Fig. 4). The excellent chemical stability of DhaTab has been confirmed by Banerjee's group [35]. The good thermostability and chemical stability revealed that the COFs could be used as catalysts or catalyst carriers.

The pore properties of DhaTab and $\left[\mathrm{SO}_{3} \mathrm{Mn}\right]-$ DhaTab were determined by nitrogen sorption isotherms measured at -196 ${ }^{\circ} \mathrm{C}$. DhaTab exhibited a typical type-IV isotherm characteristic of mesoporous materials, whereas $\left[\mathrm{SO}_{3} \mathrm{Mn}\right]$-DhaTab exhibited a type-I isotherm (Fig. 5(a)), which is characteristic of microporous materials. The BET surface areas were calculated to be 1312 and $477 \mathrm{~m}^{2} \mathrm{~g}^{-1}$, respectively. The pores were estimated to be 3.4 and $1.6 \mathrm{~nm}$ in diameter, respectively, using the NLDFT (Fig. 5(b)). The decrease in the BET surface area and pore size again indicates successful modification of DhaTab. The $\mathrm{Mn}^{2+}$ content of $\left[\mathrm{SO}_{3} \mathrm{Mn}\right]$-DhaTab was determined to be 1.9 wt $\%$ by ICP-AES, which is lower than the theoretical content (8.3 wt\%) owing to incomplete conversion in the etherification reaction of 1,3-propane sultone with the phenolic hydroxyl of DhaTab. We intended to control the grafting degree of the alkyl sulfonic acid group by controlling the reaction time because full
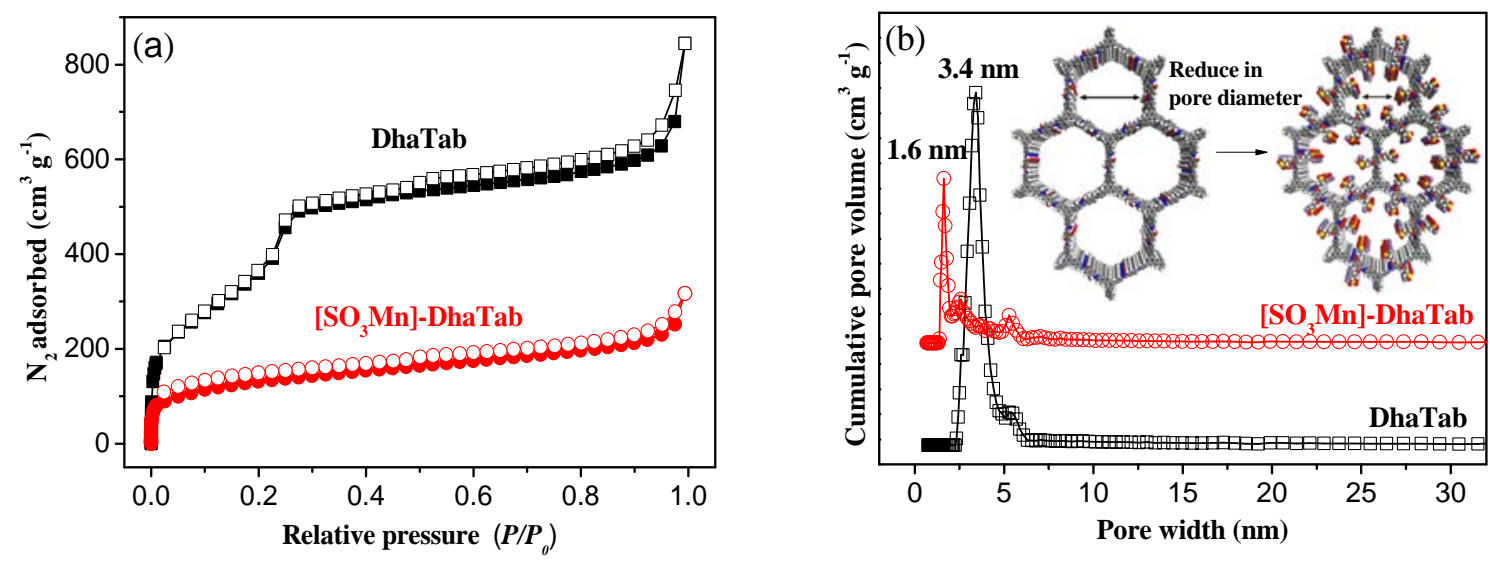

Fig. 5. Nitrogen adsorption-desorption isotherms of DhaTab and [ $\left.\mathrm{SO}_{3} \mathrm{Mn}\right]$-DhaTab (a) and their pore size distributions estimated by NLDFT (b). Adsorption (filled symbols) and desorption (open symbols). 


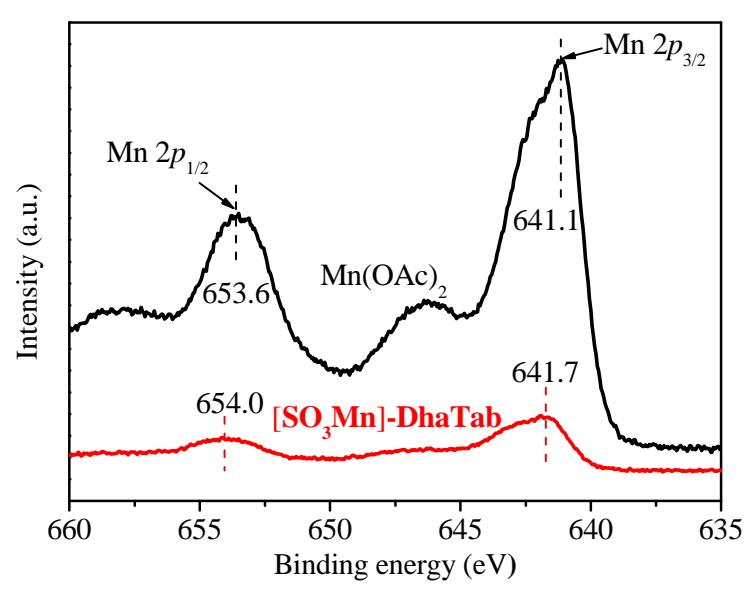

Fig. 6. XPS spectra of $\mathrm{Mn}(\mathrm{OAc})_{2}$ and $\left[\mathrm{SO}_{3} \mathrm{Mn}\right]-\mathrm{DhaTab} \mathrm{COF}$.

grafting will lead to destruction of the crystal structure. XPS was performed to determine the valence state of the exchanged manganese (Fig. 6). In comparison with those of manganese acetate $\left[\mathrm{Mn}(\mathrm{OAc})_{2}\right]$, both the $\mathrm{Mn} 2 p_{1 / 2}$ and $\mathrm{Mn} 2 p_{3 / 2}$ signals of $\left[\mathrm{SO}_{3} \mathrm{Mn}\right]$-DhaTab shifted to slightly higher energy values owing to the stronger bonding between $\mathrm{Mn}^{2+}$ and $-\mathrm{SO}_{3}{ }^{-}$. No valence change was observed for $\mathrm{Mn}^{2+}$ when it was introduced into the frameworks.

\subsection{Catalytic performance of COFs}

The I-COF with $\mathrm{Mn}^{2+}$ exchanged into the frameworks was explored for use as the heterogeneous catalyst for epoxidation of different olefins to epoxides. The epoxidation of stilbene was first used as a model reaction. A high conversion of $99 \%$ with a yield of 99\% was observed (Table 1, entry 1), showing that [ $\left.\mathrm{SO}_{3} \mathrm{Mn}\right]$-DhaTab is highly active in this reaction. To further judge the highly catalytic activity of $\left[\mathrm{SO}_{3} \mathrm{Mn}\right]-\mathrm{DhaTab}$, the epoxidation of styrene was also investigated. The conversion of styrene was $99 \%$, and the yield was $74 \%$ (Table 1, entry 4), which is higher than that for the reaction without the catalyst and for the experiment in which $\mathrm{Mn}(\mathrm{OAc})_{2}$ and $\left[\mathrm{SO}_{3} \mathrm{H}\right]-\mathrm{DhaTab}$ were used as catalysts (Table 1, entries 5 and 6).

Evidently, the conversion in this heterogeneous catalytic system is even higher than that in the homogeneous counterpart. The heterogeneity of [ $\left.\mathrm{SO}_{3} \mathrm{Mn}\right]$-DhaTab was confirmed by hot filtration of the catalysts after 30 min of reaction, which resulted in negligible additional yield of the product up to $18 \mathrm{~h}$ after filtration (Fig. 7). This indicated that $\left[\mathrm{SO}_{3} \mathrm{Mn}\right]$-DhaTab was a heterogeneous catalyst, and no catalytically active species were released into solution. The recyclability test of $\left[\mathrm{SO}_{3} \mathrm{Mn}\right]$-DhaTab clearly shows that it can be easily isolated from the reaction suspension by filtration and can be reused without significant loss of activity in the third run (Table 1 , entries 2 and 3). The crystalline structure of the scaffold of the COF was found to be well preserved after three cycles (Fig. 8(a)), and the FTIR spectrum (Fig. 8(b)) of [ $\left.\mathrm{SO}_{3} \mathrm{Mn}\right]-$ DhaTab after the third run showed almost the same patterns as the pristine one, indicating the high stability of this catalyst in the catalytic environment. We also explored a range of substrates
Table 1

Catalytic performance of different catalysts in epoxidation of olefins.

Catalyst
210

Reaction conditions: olefin $5 \mathrm{mmol}$, IBA $15 \mathrm{mmol}$, catalyst $15 \mathrm{mg}$, $\mathrm{CH}_{3} \mathrm{CN} 1.0 \mathrm{~mL}$, room temperature, $12 \mathrm{~h}$, in air.

a Second cycle. ${ }^{\mathrm{b}}$ Third cycle.

for this oxidation reaction. The conversions of cyclohexene, cyclooctene, and 1-hexene were found to be $84 \%, 82 \%$, and $80 \%$, with corresponding yields of $83 \%$, $80 \%$, and $62 \%$, respectively (entries 7-9). These results further indicate the high reactive activity of $\left[\mathrm{SO}_{3} \mathrm{Mn}\right]$-DhaTab in the epoxidation of olefins.

Ion exchange in $\left[\mathrm{SO}_{3} \mathrm{H}\right]$-DhaTab can in principle be carried out with a range of cations. Inspired by several significant studies where a known "ship-in-the bottle" approach was used

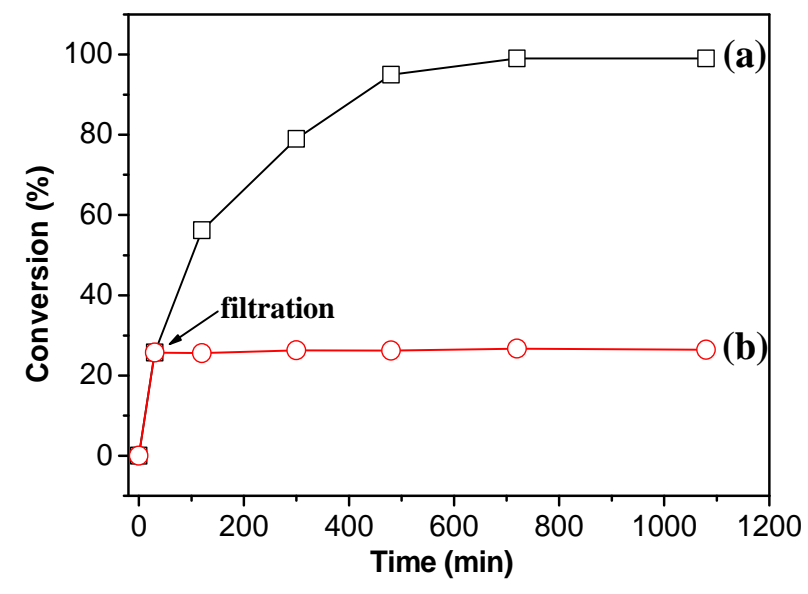

Fig. 7. Result of hot filtration test. 

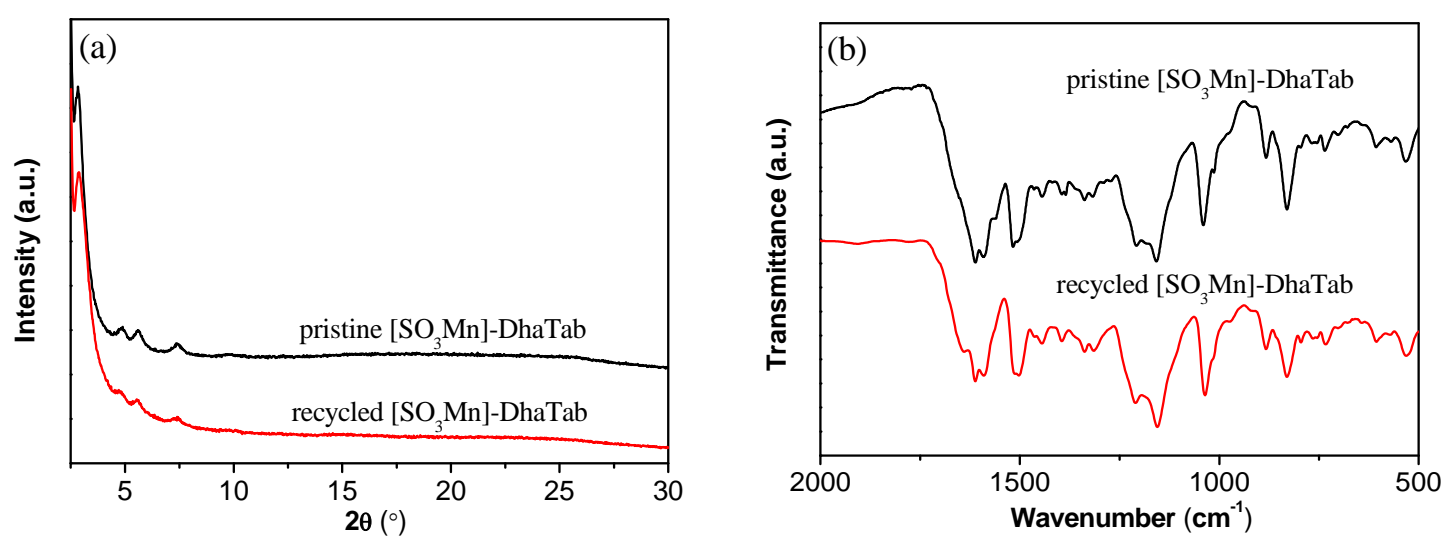

Fig. 8. Comparison of PXRD patterns (a) and FTIR spectra (b) of pristine [ $\left.\mathrm{SO}_{3} \mathrm{Mn}\right]-\mathrm{DhaTab}$ and $\left[\mathrm{SO}_{3} \mathrm{Mn}\right]-\mathrm{DhaTab}$ used for third cycle.

to immobilize transition metal complexes ([Mn(bpy $\left.\left.)_{2}\right]^{2+}\right)$, leading to improved catalytic stability and recyclability [37-40], we used a similar procedure for immobilizing $\left[\mathrm{Mn}(\mathrm{bpy})_{2}\right]^{2+}$ into the pores of $\left[\mathrm{SO}_{3} \mathrm{Mn}\right]$-DhaTab through direct complexation of $\mathrm{Mn}^{2+}$ in $\left[\mathrm{SO}_{3} \mathrm{Mn}\right]-\mathrm{DhaTab}$ and bipyridyl [40]. The epoxidation of trans-stilbene with $\left[\mathrm{SO}_{3} \mathrm{Mn}\right.$ (bpy) 2 ]-DhaTab as the catalyst was investigated. It was found that within only $1 \mathrm{~h}$, complete conversion was accomplished, with a selectivity of $99 \%$ for the formation of 2,3-diphenylethylene oxide (Table 1, entry 10). The high reactive activity of $\left[\mathrm{Mn}(\mathrm{bpy})_{2}\right]^{2+}$ was well preserved in the negatively charged I-COF.

\section{Conclusions}

In summary, we developed a post-synthetic approach to realize ionization on the channel walls of a chemically stable DhaTab COF. Either metallic $\mathrm{Mn}^{2+}$ or the transition metal complex $\left[\mathrm{Mn}(\mathrm{bpy})_{2}\right]^{2+}$ was loaded within the pores of the COF through a simple ion exchange process. The resulting [SO $\left.\mathrm{SO}_{3} \mathrm{Mn}\right]-$ DhaTab and $\left[\mathrm{SO}_{3} \mathrm{Mn}(\mathrm{bpy})_{2}\right]$-DhaTab exhibited excel- lent catalytic activity in the epoxidation of olefins to epoxides. We consider that with this type of ionic architecture, a variety of other functional cations could be exchanged into the frameworks, thus making the COF a versatile platform for different applications, such as ion exchangers and ion conductors. Moreover, we predict that the pore volume and pore size of this COF can be tailored by ion exchange so that these parameters can be adjusted for adsorption and separation of gas molecules.

\section{References}

[1] A. P. Côté, A. I. Benin, N. W. Ockwig, M. O'Keeffe, A. J. Matzger, O. M. Yaghi, Science, 2005, 310, 1166-1170.

[2] H. M. El-Kaderi, J. R. Hunt, J. L. Mendoza-Cortés, A. P. Côté, R. E. Taylor, M. O'Keeffe, O. M. Yaghi, Science, 2007, 316, 268-272.

[3] X. Feng, X. S. Ding, D. L. Jiang, Chem. Soc. Rev., 2012, 41, 6010-6022.

[4] S. Y. Ding, W. Wang, Chem. Soc. Rev., 2013, 42, 548-568.

[5] S. S. Han, H. Furukawa, O. M. Yaghi, W. A. Goddard III, J. Am. Chem. Soc., 2008, 130, 11580-11581.

[6] H. Furukawa, O. M. Yaghi, J. Am. Chem. Soc., 2009, 131, 8875-8883.

\section{Graphical Abstract}

Chin. J. Catal., 2018, 39: 1437-1444 doi: 10.1016/S1872-2067(18)63065-7

\section{Ionic covalent organic frameworks for highly effective catalysis}

Hui Hu, Qianqian Yan, Ming Wang, Li Yu, Wei Pan, Baoshan Wang,

Yanan Gao*

Hainan University;

Shandong University;

Shandong Normal University;

Wuhan University

An ionic covalent organic framework (I-COF) was constructed via post-synthetic modification. This material was endowed with high catalytic performance through ion exchange of functional counter ions. The versatile I-COFs exhibited excellent catalytic activity in epoxidation reactions.

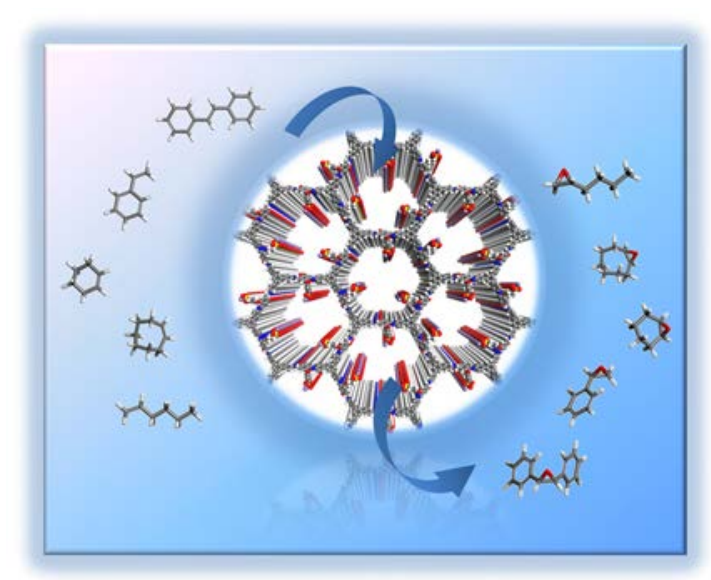


[7] C. J. Doonan, D. J. Tranchemontagne, T. G. Glover, J. R. Hunt, O. M. Yaghi, Nat. Chem., 2010, 2, 235-238.

[8] H. P. Ma, H. Ren, S. Meng, Z. J. Yan, H. Y. Zhao, F. X. Sun, G. S. Zhu, Chem. Commun., 2013, 49, 9773-9775.

[9] M. G. Rabbani, A. K. Sekizkardes, Z. Kahveci, T. E. Reich, R. S. Ding, H. M. El-Kaderi, Chem. Eur. J., 2013, 19, 3324-3328.

[10] S. Dalapati, S. B. Jin, J. Gao, Y. H. Xu, A. Nagai, D. L. Jiang, J. Am. Chem. Soc., 2013, 135, 17310-17313.

[11] J. Zhang, L. B. Wang, N. Li, J. F. Liu, W. Zhang, Z. B. Zhang, N. C. Zhou, X. L. Zhu, CrystEngComm, 2014, 16, 6547-6551.

[12] S. Wan, J. Guo, J. Kim, H. Ihee, D. L. Jiang, Angew. Chem. Int. Ed., 2008, 47, 8826-8830.

[13] S. Wan, J. Guo, J. Kim, H. Ihee, D. L. Jiang, Angew. Chem. Int. Ed., 2009, 48, 5439-5442.

[14] X. Feng, L. Chen, Y. Honsho, O. Saengsawang, L. L. Liu, L. Wang, A. Saeki, S. Irle, S. Seki, Y. P. Dong, D. L. Jiang, Adv. Mater., 2012, 24, 3026-3031.

[15] E. L. Spitler, J. WColson, F. J. Uribe-Romo, A. R. Woll, M. R. Giovino, A. Saldivar, W. R. Dichtel, Angew. Chem. Int. Ed., 2012, 51, 2623-2627.

[16] M. Dogru, M. Handloser, F. Auras, T. Kunz, D. Medina, A. Hartschuh, P. Knochel, T. Bein, Angew. Chem. Int. Ed., 2013, 52, 2920-2924.

[17] L. Chen, K. Furukawa, J. Gao, A. Nagai, T. Nakamura, Y. P. Dong, D. L. Jiang, J. Am. Chem. Soc., 2014, 136, 9806-9809.

[18] C. R. DeBlase, K. E. Silberstein, T. T. Truong, H. D. Abruña, W. R. Dichtel, J. Am. Chem. Soc., 2013, 135, 16821-16824.

[19] L. Stegbauer, K. Schwinghammer, B. V. Lotsch, Chem. Sci., 2014, 5, 2789-2793.

[20] W. G. Leng, Y. S. Peng, J. Q. Zhang, H. Lu, X. Feng, R. L. Ge, B. Dong, B. Wang, X. P. Hu, Y. A. Gao, Chem. Eur. J., 2016, 22, 9087-9091.

[21] Q. Sun, B. Aguila, J. Perman, N. Nguyen, S. Q. Ma, J. Am. Chem. Soc., 2016, 138, 15790-15796.

[22] S. L. Lu, Y. M. Hu, S. Wan, R. McCaffrey, Y. H. Jin, H. W. Gu, W. Zhang, J. Am. Chem. Soc., 2017, 139, 17082-17088.

[23] H. Li, Q. Y. Pan, Y. C Ma, X. Y. Guan, M. Xue, Q. R. Fang, Y. S. Yan, V.
Valtchev, S. L. Qiu, J. Am. Chem. Soc., 2016, 138, 14783-14788.

[24] X. R. Wang, X. Han, J. Zhang, X. W. Wu, Y. Liu, Y. Cui, J. Am. Chem. Soc., 2016, 138, 12332-12335.

[25] J. Zhang, X. Han, X. W. Wu, Y. Liu, Y. Cui, J. Am. Chem. Soc., 2017, $139,8277-8285$.

[26] H. Xu, J. Gao, D. L. Jiang, Nat. Chem., 2015, 7, 905-912.

[27] J. Q. Zhang, Y. S. Peng, W. G. Leng, Y. A. Gao, F. F. Xu, J. L. Chai, Chin. J. Catal., 2016, 37, 468-475.

[28] Q. R. Fang, G. S. Zhu, M. Xue, J. Y. Sun, Y. Wei, S. R. Qiu, R. R. Xu, Angew. Chem. Int. Ed., 2005, 44, 3845-3848.

[29] Y. J. Cui, Y. F. Yue, G. D. Qian, B. L. Chen, Chem. Rev., 2012, 112, 1126-1162.

[30] J. A. Johnson, X. Zhang, X. Zhang, J. Zhang, Curr. Org. Chem., 2014, $18,1973-2001$.

[31] H. P. Ma, B. L. Liu, B. Li, L. M. Zhang, Y. G. Li, H. Q. Tan, H. Y. Zang, G. S. Zhu, J. Am. Chem. Soc., 2016, 138, 5897-5903.

[32] N. Huang, P. Wang, M. A. Addicoat, T. Heine, D. L. Jiang, Angew. Chem. Int. Ed., 2017, 56, 4982-4986.

[33] Y. Y. Zhang, J. Y. Duan, D. Ma, P. F. Li, S. W. Li, H. W. Li, J. W. Zhou, X. J. Ma, X. Feng, B. Wang, Angew. Chem. Int. Ed., 2017, 56, 16313-16317.

[34] Y. Du, H. S. Yang, J. M. Whiteley, S. Wan, Y. H. Jin, S. Lee, W. Zhang, Angew. Chem. Int. Ed., 2016, 55, 1737-1741.

[35] S. Kandambeth, V. Venkatesh, D. B. Shinde, S. Kumari, A. Halder, S. Verma, R. Banerjee, Nat. Commun., 2015, 6, 6786-6795.

[36] T. Kretz, J. W. Bats, H. W. Lerner, M. Wagner, Z. Naturforsch B, 2007, 62, 66-74.

[37] P. P. Knops-Gerrits, D. D. Vos, F. T. Starzyk, P. A. Jacobs, Nature, 1994, 369, 543-546.

[38] F. Farzaneh, M. Majidian, M. Ghandi, J. Mol. Catal. A, 1999, 148, 227-233.

[39] M. Salavati-Niasari, F. Farzaneh, M. Ghandi, J. Mol. Catal. A, 2002, 186, 101-107.

[40] S. Fischer, J. Schmidt, P. Strauch, A. Thomas, Angew. Chem. Int. Ed., 2013, 52, 12174-12178.

\title{
离子型共价有机框架材料的合成及其催化性能
}

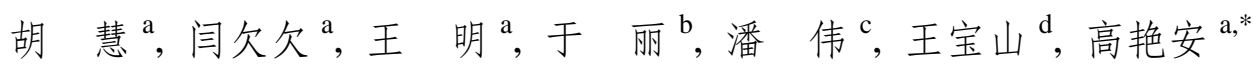 \\ a 海南大学热带岛屿资源先进材料教育部重点实验室, 海南海口 570228 \\ b 山东大学胶体与界面化学教育部重点实验室, 山东济南 250100 \\ c山东师范大学化学化工与材料科学学院, 山东济南 250014 \\ $\mathrm{d}$ 武汉大学化学与分子科学学院, 湖北武汉 430072
}

摘要: 共价有机框架 (COFs) 材料是在拓扑学基础上发展起来的一类新型有机晶体多孔聚合物. 由于 COFs 材料具有较高 的比表面积、良好的热稳定性和化学稳定性、可设计的孔结构以及容易修饰改性的特点, 目前广泛用作催化剂或催化剂载 体. COFs 的构筑单体为有机小分子, 其来源广泛且种类繁多, 使得构筑单体多样化, 便于通过构筑单体来调控目标材料的 结构和功能. 近年来对 COFs 的研究已经引起人们广泛关注. 离子框架材料在气体分子的吸附与分离领域展示了良好性 能, 通过简单的离子交换过程, 可以容易地将具有特定尺寸和功能的反离子引入到框架结构中来调控孔的尺寸大小, 从而 实现混合气体的有效分离. 然而, 在催化领域目前尚未见将具有特定催化功能的反离子基团引入到框架之中, 研究离子框 架材料的催化性能.

本文设计合成了一种负电荷为骨架结构的离子型 COFs 材料. 我们首先选取一种化学结构稳定的 COF 作为骨架前驱 体, 其中的单体具有可反应的活性基团酚羟基, 然后通过与 1,3-丙烷磺酸内酯进行开环反应, 将烷基磺酸引入到孔中, 经过 弱碱处理后得到阴离子型 COFs (I-COFs), 然后通过简单的离子交换过程将具有催化活性的 $\mathrm{Mn}^{2+}$ 以及 $\left[\mathrm{Mn}(\mathrm{bpy})_{2}\right]^{2+}$ 配位阳 离子分别引入到 COFs 框架中, 得到具有催化功能的新材料. 我们考察了两种 I-COFs 对烯烃氧化制环氧化合物的催化性 能, 发现所得离子 COFs 对不同的反应底物均展示了较高的环氧化催化性能. 结果证实了离子 I-COF 催化反应为多相催 
化, 还表现出 I-COFs 催化剂具有较高的稳定性以及循环使用性能. 我们认为, 通过简单的离子交换过程, 能够赋予 I-COFs 材料各种不同的功能, 从而实现 COFs 在不同领域的应用. 这为多孔材料的功能化设计提供了新的化学平台.

关键词: 共价有机框架材料; 离子骨架; 催化; 环氧化; 多孔材料

收稿日期: 2018-02-15. 接受日期: 2018-03-23. 出版日期: 2018-09-05.

*通讯联系人. 电话/传真: (0898)66279161; 电子信箱: ygao@hainu.edu.cn

基金来源：国家自然科学基金(21473196, 21676264); 中国科学院“百人计划”; 大连理工大学精细化工国家重点实验室开放课题 (KF1415).

本文的电子版全文由Elsevier出版社在ScienceDirect上出版(http://www.sciencedirect.com/science/journal/18722067). 